\title{
Energy and sustainable development in Nigeria: the way forward
}

\author{
Sunday Olayinka Oyedepo
}

\begin{abstract}
Access to clean modern energy services is an enormous challenge facing the African continent because energy is fundamental for socioeconomic development and poverty eradication. Today, $60 \%$ to $70 \%$ of the Nigerian population does not have access to electricity. There is no doubt that the present power crisis afflicting Nigeria will persist unless the government diversifies the energy sources in domestic, commercial, and industrial sectors and adopts new available technologies to reduce energy wastages and to save cost. This review examines a set of energy policy interventions, which can make a major contribution to the sustainable economic, environmental, and social development of Africa's most populated country, Nigeria. Energy efficiency leads to important social benefits, such as reducing the energy bills for poor households. From an economic point of view, implementing the country's renewable energy target will have significant costs, but these can partly be offset by selling carbon credits according to the rules of the 'Clean Development Mechanism' agreed some 10 years ago, which will result in indirect health benefits.

Nigeria could benefit from the targeted interventions that would reduce the local air pollution and help the country to tackle greenhouse gas emissions. Many factors that need to be considered and appropriately addressed in the shift to its sustainable energy future are examined in this article. These include a full exploitation and promotion of renewable energy resources, energy efficiency practices, as well as the application of energy conservation measures in various sectors such as in the construction of industrial, residential, and office buildings, in transportation, etc.
\end{abstract}

Keywords: Sustainable energy, Renewable energy, Energy efficiency, Energy conservation

\section{Review}

\section{Background}

Energy plays the most vital role in the economic growth, progress, and development, as well as poverty eradication and security of any nation. Uninterrupted energy supply is a vital issue for all countries today. Future economic growth crucially depends on the long-term availability of energy from sources that are affordable, accessible, and environmentally friendly. Security, climate change, and public health are closely interrelated with energy [1]. Energy is an important factor in all the sectors of any country's economy. The standard of living of a given country can be directly related to the per capita energy consumption. The recent world's energy crisis is due to two reasons: the rapid population growth

*Correspondence: sunday.oyedepo@covenantuniversity.edu.ng Mechanical Engineering Department, Covenant University, Ota 2023, Nigeria and the increase in the living standard of whole societies. The per capita energy consumption is a measure of the per capita income as well as a measure of the prosperity of a nation [2].

Energy supports the provision of basic needs such as cooked food, a comfortable living temperature, lighting, the use of appliances, piped water or sewerage, essential health care (refrigerated vaccines, emergency, and intensive care), educational aids, communication (radio, television, electronic mail, the World Wide Web), and transport. Energy also fuels productive activities including agriculture, commerce, manufacturing, industry, and mining. Conversely, a lack of access to energy contributes to poverty and deprivation and can contribute to the economic decline. Energy and poverty reduction are not only closely connected with each other, but also with the socioeconomic development, which involves productivity, income growth, education, and health [3].

\section{实}


The energy crisis, which has engulfed Nigeria for almost two decades, has been enormous and has largely contributed to the incidence of poverty by paralyzing industrial and commercial activities during this period. The Council for Renewable Energy of Nigeria estimates that power outages brought about a loss of 126 billion naira (US\$ 984.38 million) annually [4]. Apart from the huge income loss, it has also resulted in health hazards due to the exposure to carbon emissions caused by constant use of 'backyard generators' in different households and business enterprises, unemployment, and high cost of living leading to a deterioration of living conditions.

Moreover, according to the Central Bank estimate in 1985, Nigeria consumed $8,771,863$ tonnes of oil equivalent [5]. This is equal to about 180,000 barrels of oil per day. Since then, oil consumption in Nigeria has drastically increased. The effect of this increase on the economy relying solely on revenue from oil is tremendous. Also, the Department for Petroleum Resources [6] reported an amount of petroleum of more than $78 \%$ of the total energy consumption in Nigeria. In the present predicament as a nation, it is obvious that depending mainly on fossil fuel (petroleum) is not enough to meet the energy needs of the country. Since Nigeria is blessed with abundant renewable energy resources such as hydroelectric, solar, wind, tidal, and biomass, there is a need to harness these resources and chart a new energy future for Nigeria. In this regard, the government has a responsibility to make renewable energy available and affordable to all.

Many indigenous researchers have looked into the availability of renewable energy resources in Nigeria with a view to establishing their viability in the country. Onyebuchi [7] estimated the technical potential of solar energy in Nigeria with a 5\% device conversion efficiency put at $15.0 \times 10^{14} \mathrm{~kJ}$ of useful energy annually. This equates to about 258.62 million barrels of oil equivalent annually, which corresponds to the current national annual fossil fuel production in the country. This will also amount to about $4.2 \times 10^{5} \mathrm{GW} / \mathrm{h}$ of electricity production annually, which is about 26 times the recent annual electricity production of $16,000 \mathrm{GW} / \mathrm{h}$ in the country. In their work, Chineke and Igwiro [8] show that Nigeria receives abundant solar energy that can be usefully harnessed with an annual average daily solar radiation of

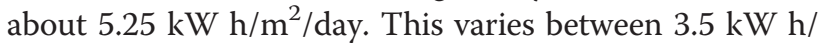
$\mathrm{m}^{2} /$ day at the coastal areas and $7 \mathrm{~kW} \mathrm{~h} / \mathrm{m}^{2} /$ day at the northern boundary. The average amount of sunshine hours all over the country is estimated to be about $6.5 \mathrm{~h}$. This gives an average annual solar energy intensity of $1,934.5 \mathrm{~kW} \mathrm{~h} / \mathrm{m}^{2} /$ year; thus, over the course of a year, an average of 6,372,613 $\mathrm{PJ} /$ year (approximately 1,770 $\mathrm{TW} h$ /year) of solar energy falls on the entire land area of Nigeria. This is about 120,000times the total annual average electrical energy generated by the Power Holding Company of Nigeria (PHCN). With a $10 \%$ conservative conversion efficiency, the available solar energy resource is about 23 times the Energy Commission of Nigeria's (ECN) projection of the total final energy demand for Nigeria in the year 2030 [9]. To enhance the developmental trend in the country, there is every need to support the existing unreliable energy sector with a sustainable source of power supply through solar energy.

Moreover, many indigenous researchers have also explored the availability of wind energy sources in $\mathrm{Ni}$ geria with a view of implementing them if there is a likelihood for their usage. Adekoya and Adewale [10] analyzed the wind speed data of 30 stations in Nigeria, determining the annual mean wind speeds and power flux densities, which vary from 1.5 to $4.1 \mathrm{~m} / \mathrm{s}$ to 5.7 to $22.5 \mathrm{~W} / \mathrm{m}^{2}$, respectively. Fagbenle and Karayiannis [11] carried out a 10-year wind data analysis from 1979 to 1988, considering the surface and upper winds as well as the maximum gusts, whereas Ngala et al. [12] performed a statistical analysis of the wind energy potential in Maiduguri, Borno State, using the Weibull distribution and 10-year (1995 to 2004) wind data. A cost benefit analysis was also performed using the wind energy conversion systems for electric power generation and supply in the State. Each of these reports point to the fact that the nation is blessed with a vast opportunity for harvesting wind for electricity production, particularly at the core northern states, the mountainous parts of the central and eastern states, and also the offshore areas, where wind is abundantly available throughout the year. The issue then is for the country to look at ways of harnessing resources towards establishing wind farms in various regions and zones that have been identified as possessing abilities for the harvesting of wind energy.

Akinbami [13] reported that the total hydroelectric power potential of the country was estimated to be about $8,824 \mathrm{MW}$ with an annual electricity generation potential in excess of $36,000 \mathrm{GW} \mathrm{h}$. This consists of 8,000 MW of large hydropower technology, while the remaining $824 \mathrm{MW}$ is still small-scale hydropower technology. Presently, $24 \%$ and $4 \%$ of both large and small hydropower potentials, respectively, in the country have been exploited.

Akinbami et al.'s assessment [14] indicated that the identified feedstock substrate for an economically feasible biogas program in Nigeria includes water lettuce, water hyacinth, dung, cassava leaves, urban refuse, solid (including industrial) waste, agricultural residues, and sewage. The authors' views include the following: Nigeria produces about 227,500 tonnes of fresh animal wastes daily. Since $1 \mathrm{~kg}$ of fresh animal wastes produces about $0.03 \mathrm{~m}^{3}$ gas, then Nigeria could produce about 6.8 million $\mathrm{m}^{3}$ of biogas every day. In addition to all these, 
$20 \mathrm{~kg}$ of municipal solid wastes per capital has been estimated to be generated in the country annually.

The prime objectives of this paper are (1) to review the current status of the energy resources, the energy demand, and supply in Nigeria and (2) to explore the prospects of utilizing renewable energy resources and to increase the energy efficiency as a possible means of sustainable development in Nigeria.

\section{Energy situation in Nigeria}

Nigeria is Africa's energy giant. It is the continent's most prolific oil-producing country, which, along with Libya, accounts for two-thirds of Africa's crude oil reserves. It ranks second to Algeria in natural gas [15]. Most of Africa's bitumen and lignite reserves are found in Nigeria. In its mix of conventional energy reserves, Nigeria is simply unmatched by any other country on the African continent. It is not surprising therefore that energy export is the mainstay of the Nigerian economy. Also, primary energy resources dominate the nation's industrial raw material endowment.

Several energy resources are available in Nigeria in abundant proportions. The country possesses the world's sixth largest reserve of crude oil. Nigeria has an estimated oil reserve of 36.2 billion barrels. It is increasingly an important gas province with proven reserves of nearly 5,000 billion $\mathrm{m}^{3}$. The oil and gas reserves are mainly found and located along the Niger Delta, Gulf of Guinea, and Bight of Bonny. Most of the exploration activities are focused in deep and ultra-deep offshore areas with planned activities in the Chad basin, in the northeast. Coal and lignite reserves are estimated to be 2.7 billion tons, while tar sand reserves represent 31 billion barrels of oil equivalent. The identified hydroelectricity sites have an estimated capacity of about 14,250 MW. Nigeria has significant biomass resources to meet both traditional and modern energy uses, including electricity generation [16]. Table 1 shows Nigeria's energy reserves/ potentials. There has been a supply and demand gap as a result of the inadequate development and inefficient management of the energy sector. The supply of electricity, the country's most used energy resource, has been erratic [17].

The situation in the rural areas of the country is that most end users depend on fuel wood. Fuel wood is used by over $70 \%$ of Nigerians living in the rural areas. $\mathrm{Ni}$ geria consumes over 50 million tonnes of fuel wood annually, a rate which exceeds the replenishment rate through various afforestation programs. Sourcing fuel wood for domestic and commercial uses is a major cause of desertification in the arid-zone states and erosion in the southern part of the country. The rate of deforestation is about 350,000 ha/year, which is equivalent to $3.6 \%$ of the present area of forests and woodlands,
Table 1 Nigeria's energy reserves/capacity as in December 2005

\begin{tabular}{|c|c|c|c|}
\hline Resource type & Reserves & $\begin{array}{l}\text { Reserves } \\
\text { (BTOE) }^{c}\end{array}$ & $\begin{array}{l}\text { Reserves } \\
\left(\times 10^{7}\right) \mathrm{TJ} \\
\end{array}$ \\
\hline Crude oil & 36.2 billion barrels & 4.896 & 20.499 \\
\hline Natural gas & 166 trillion $\mathrm{SCF}^{\mathrm{a}}$ & 4.465 & 18.694 \\
\hline Coal and lignite & 2.7 billion tonnes & 1.882 & 7.879 \\
\hline Tar sands & $\begin{array}{l}31 \text { billion barrels of } \\
\text { oil equivalent }\end{array}$ & 4.216 & 17.652 \\
\hline Subtotal Fossil & & 15.459 & 64.724 \\
\hline $\begin{array}{l}\text { Hydropower, } \\
\text { large Scale }\end{array}$ & $11,000 \mathrm{MW}$ & & $0.0341 /$ year \\
\hline $\begin{array}{l}\text { Hydropower, } \\
\text { small Scale }\end{array}$ & $3,250 \mathrm{MW}$ & & 0.0101/year \\
\hline Fuel wood & $13,071,464 \mathrm{ha}^{\mathrm{b}}$ & & \\
\hline Animal waste & 61 million tonnes/year & & \\
\hline Crop residue & 83 million tonnes/year & & \\
\hline Solar radiation & 3.5 to $7.0 \mathrm{~kW} \mathrm{~h} / \mathrm{m}^{2} /$ day & & \\
\hline Wind & $\begin{array}{l}2 \text { to } 4 \mathrm{~m} / \mathrm{s} \text { (annual average) } \\
\text { at } 10 \mathrm{~m} \text { in height }\end{array}$ & & \\
\hline
\end{tabular}

${ }^{a} \mathrm{SCF}$, standard cubic feet; ${ }^{\mathrm{b}}$ forest land estimate for $1981 ;{ }^{\mathrm{C}} \mathrm{BTOE}$, billion tonnes of oil equivalent. Adapted from ECN [18].

whereas reforestation is only at about $10 \%$ of the deforestation rate [19].

The rural areas, which are generally inaccessible due to the absence of good road networks, have little access to conventional energy such as electricity and petroleum products. Petroleum products such as kerosene and gasoline are purchased in the rural areas at prices $150 \%$ in excess of their official pump prices. The daily needs of the rural populace for heat energy are therefore met almost entirely from fuel wood. The sale of fuel wood and charcoal is mostly uncontrolled in the unorganized private sector. The sale of kerosene, electricity and cooking gas is essentially influenced and controlled by the Federal Government or its agencies - the Nigerian National Petroleum Corporation (NNPC) in the case of kerosene and cooking gas, and the PHCN in the case of electricity. The policy of the Federal Government had been to subsidize the pricing of locally consumed petroleum products, including electricity. In a bid to make the petroleum downstream sector more efficient and in an attempt to stem petroleum product consumption as a policy focus, the government has reduced and removed subsidies on various energy resources in Nigeria. The various policy options have always engendered price increases of the products [20].

With the restructuring of the power sector and the imminent privatization of the electricity industry, it is obvious that for logistic and economic reasons especially in the privatized power sector, rural areas that are remote from the grid and/or have low consumption or low 
power purchase potential will not be attractive to private power investors. Such areas may remain unserved into the distant future [21].

Meanwhile, electricity is required for such basic developmental services as pipe borne water, health care, telecommunications, and quality education. The poverty eradication and Universal Basic Education programs require energy for success. The absence of reliable energy supply has not only left the rural populace socially backward, but has also left their economic potentials untapped. Fortunately, Nigeria is blessed with abundant renewable energy resources such as solar, wind, biomass, and small hydropower potentials. The logical solution is increased penetration of renewables into the energy supply mix [15].

\section{Energy consumption pattern in Nigeria}

Energy consumption patterns in the world today shows that Nigeria and indeed African countries have the lowest rates of consumption. Nevertheless, Nigeria suffers from an inadequate supply of usable energy due to the rapidly increasing demand, which is typical of a developing economy. Paradoxically, the country is potentially endowed with sustainable energy resources. Nigeria is rich in conventional energy resources, which include oil, national gas, lignite, and coal. It is also well endowed with renewable energy sources such as wood, solar, hydropower, and wind [17].

The patterns of energy usage in Nigeria's economy can be divided into industrial, transport, commercial, agricultural, and household sectors [22]. The household sector accounts for the largest share of energy usage in the country - about $65 \%$. This is largely due to the low level of development in all the other sectors.

The major energy-consuming activities in Nigeria's households are cooking, lighting, and use of electrical appliances. Cooking accounts for a staggering $91 \%$ of household energy consumption, lighting uses up to $6 \%$, and the remaining 3\% can be attributed to the use of basic electrical appliances such as televisions and pressing irons [9].

The predominant energy resources for domestic and commercial uses in Nigeria are fuel wood, charcoal, kerosene, cooking gas and electricity [20]. Other sources, though less common, are sawdust, agricultural crop residues of corn stalk, cassava sticks, and, in extreme cases, cow dung. In Nigeria, among the urban dwellers, kerosene and gas are the major cooking fuels. The majority of the people rely on kerosene stoves for domestic cooking, while only a few use gas and electric cookers [23].

The rural areas have little access to conventional energy such as electricity and petroleum products due to the absence of good road networks. Petroleum products such as kerosene and gasoline are purchased in the rural areas at prices very high in excess of their official pump prices. The rural population, whose needs are often basic, therefore depends to a large extent on fuel wood as a major traditional source of fuel. It has been estimated that about $86 \%$ of rural households in Nigeria depend on fuel wood as their source of energy [24]. A fuel wood supply/demand imbalance in some parts of the country is now a real threat to the energy security of the rural communities [22].

The energy consumption per capita in Nigeria is very small - about one-sixth of the energy consumed in developed countries. This is directly linked to the level of poverty in the country. Gross domestic product (GDP) and per capita income are indices that are used to measure the economic well-being of a country and its people [25]. GDP is defined as the total market value of all final goods and services produced within a given country in a given period of time (usually a calendar year). The per capita income refers to how much each individual receives, in monetary terms, of the yearly income that is generated in his/her country through productive activities. That is what each citizen would receive if the yearly income generated by a country from its productive activities were divided equally between everyone.

\section{Current electricity situation in Nigeria}

The electricity system in Nigeria centers on PHCN, which accounts for about $98 \%$ of the total electricity generation [26]. Power generation by other agencies such as the Nigerian Electricity Supply Company relies on thermal power for electricity generation unlike PHCN, which relies on both hydro- and thermal power. However, electricity is also a consumer of fuel and energy such as fuel oil, natural gas, and diesel oil. The importance of these sources of energy and fuel for generating electricity has been decreasing in recent years. However, hydropower that is relatively cheaper than these sources has grown to be more important than other sources [27]. However, more recently, the Power Authority has generated electricity through a mix of both thermal and hydro systems. All the power, distribution, and substations are specially interlinked by a transmission network popularly known as the national grid. The entire electricity generated nationwide is pooled into the National Control Centre, Osogbo, from where electricity is distributed to all parts of Nigeria.

The national electricity grid presently consists of 14 generating stations ( 3 hydro and 11 thermal) with a total installed capacity of about 8,039 MW as shown in Table 2. The transmission network is made up of $5,000 \mathrm{~km}$ of $330-\mathrm{kV}$ lines, $6,000 \mathrm{~km}$ of $132-\mathrm{kV}$ lines, 23 of $330 / 132-\mathrm{kV}$ substations, with a combined capacity of 6,000 or 4,600 MVA at a utilization factor of $80 \%$. In turn, the 91 of $132 / 33-\mathrm{kV}$ substations have a combined 
Table 2 Summary of generation capabilities of PHCN power stations as operated in 2008 (January to December)

\begin{tabular}{|c|c|c|c|c|c|c|c|c|}
\hline Plant & Operator & $\begin{array}{l}\text { Age } \\
\text { (year) }\end{array}$ & Type & $\begin{array}{l}\text { Installed } \\
\text { capacity } \\
(\mathrm{MW})\end{array}$ & $\begin{array}{l}\text { Average } \\
\text { availability } \\
\text { (MW) }\end{array}$ & $\begin{array}{l}\text { Availability } \\
\text { factor }\end{array}$ & $\begin{array}{l}\text { Number } \\
\text { of units } \\
\text { installed }\end{array}$ & $\begin{array}{l}\text { Current } \\
\text { number } \\
\text { available }\end{array}$ \\
\hline Kainji & $\mathrm{PHCN}$ & 38 to 40 & Hydro & 760 & 438.86 & 0.58 & 8 & 6 \\
\hline Jebba & $\mathrm{PHCN}$ & 25 & Hydro & 578.4 & 529.40 & 0.92 & 6 & 4 \\
\hline Shiroro & PHCN & 22 & Hydro & 600 & 488.82 & 0.81 & 4 & 4 \\
\hline Egbin & PHCN & 23 & ST & 1320 & 694.97 & 0.53 & 6 & 5 \\
\hline AES & AES & 7 & GT & 315 & 233.91 & 0.77 & 9 & 9 \\
\hline Ajaokuta & STS & NA & GT & 110 & 24.88 & 0.23 & 2 & 2 \\
\hline Sapele & $\mathrm{PHCN}$ & 26 to 30 & ST/GT & 1020 & 156.60 & 0.15 & 10 & 1 \\
\hline Okpai & AGIP & 3 & GT/ST & 480 & 394.56 & 0.88 & 3 & 3 \\
\hline Afam & $\mathrm{PHCN}$ & 8 to 45 & GT & 709.6 & 82.12 & 0.09 & 20 & 3 \\
\hline Delta & PHCN & 18 & GT & 912 & 211.67 & 0.24 & 18 & 12 \\
\hline Geregu & PHCN & NA & GT & 414 & 305.14 & 0.74 & 3 & 3 \\
\hline Omoku & RS & 3 & GT & 150 & 87.27 & 0.87 & 6 & 4 \\
\hline Omotosho & $\mathrm{PHCN}$ & 1 & GT & 335 & 256.58 & 0.77 & 8 & 2 \\
\hline Olorunsogo & PHCN & 1 & GT & 335 & 271.46 & 0.81 & 8 & 2 \\
\hline Total & & & & 8,039 & 4176.24 & 0.50 & 93 & 45 \\
\hline
\end{tabular}

Adapted from PHCN [30].

capacity of 7,800 or 5,800 MVA at a utilization factor of $75 \%$. The distribution sector is comprised of $23,753 \mathrm{~km}$ of $33-\mathrm{kV}$ lines, $19,226 \mathrm{~km}$ of $11-\mathrm{kV}$ lines, and 679 of 33/ $11-\mathrm{kV}$ substations. There are also 1,790 distribution transformers and 680 injection substations [28]. Table 2 shows a summary of the generation capabilities of PHCN power stations as operated in the year 2008 (January to December) [29].

As it can be seen in Table 2, the existing plants operate at far below their installed capacity as many of them have units that need to be rehabilitated, retrofitted, and upgraded [31]. The percentage of generation capability from hydro turbines is $34.89 \%$; from gas turbine, $35.27 \%$; and from steam turbines, $29.84 \%$. The relative contribution of the hydropower stations to the total electricity generation (megawatt per hour) is greater than that of the thermal power stations.

In terms of the consumption of electricity, a classification into three groups has been proposed (industrial, residential, and street light consumption). In 1970, the total electricity consumption stood at $145.3 \mathrm{MW} / \mathrm{h}$; this increased to about $536.9 \mathrm{MW} / \mathrm{h}$ in 1980 . However, in 2005 , the total electricity consumption had increased to $1,873.1 \mathrm{MW} / \mathrm{h}$ [32]. On the generation side, these values of $176.6 \mathrm{MW} / \mathrm{h}$ in 1970 increased to $815.1 \mathrm{MW} / \mathrm{h}$ in 1980. By the end of 2005, the achieved total electricity generation was 2,997.3 MW/h [32]. Comparing the per capita power generation to that of other countries, Nigeria has the lowest among the countries, as shown in Table 3, while the USA has the highest per capita electricity generation.
In spite of the contribution of electricity to the total gross domestic product, it is evident that Nigeria is facing several problems. The incapacity of the electricity subsector to efficiently meet the demand for electricity in the country has been caused by a number of problems, which have been detrimental to economic growth. The Central Bank of Nigeria [26] has identified nine problems associated with the National Electric Power Authority (NEPA) (now PHCN):

1. Lack of preventive and routine maintenance of NEPA's facilities, resulting in huge energy losses.

2. Frequent major breakdowns, arising from the use of outdated and heavily overloaded equipment.

Table 3 Country statistics of electricity generation and per capita consumption

\begin{tabular}{lllll}
\hline Continent & Country & $\begin{array}{l}\text { Population } \\
\text { (million) }\end{array}$ & $\begin{array}{l}\text { Generation } \\
\text { capacity } \\
\text { (MW) }\end{array}$ & $\begin{array}{l}\text { Per capita } \\
\text { consumption } \\
\text { (kW) }\end{array}$ \\
\hline North America & USA & 250 & 813,000 & 3.2 \\
South America & Cuba & 10.54 & 4,000 & 0.38 \\
Europe (central) & UK & 57.5 & 76,000 & 1.1 \\
Europe (eastern) & Ukraine & 49 & 54,000 & 1.33 \\
Middle East & Iraq & 23.6 & 10,000 & 0.42 \\
Far East & South Korea & 47 & 52,000 & 1.10 \\
Africa & Nigeria & 140 & $<4,000$ & 0.03 \\
& Egypt & 67.9 & 18,000 & 0.27 \\
& South Africa & 44.3 & 45,000 & 1.02 \\
\hline
\end{tabular}

Adapted from Okafor and Joe-Uzuegbu [17]. 
3. Lack of coordination between town planning authorities and $\mathrm{PHCN}$, resulting in poor overall power system planning and overloading of $\mathrm{PHCN}$ equipment.

4. Inadequate generation due to operational/technical problems arising from machine breakdown, low gas pressure, and low water levels.

5. Poor funding of the organization.

6. Inadequate budgetary provision and undue delay in release of funds to $\mathrm{PHCN}$.

7. PHCN's inefficient billing and collection system.

8. High indebtedness to PHCN by both public and private consumers who are reluctant to pay for electricity consumed when due.

9. Vandalizing and pilfering of $\mathrm{PHCN}$ equipment.

In addition to these, most of the existing electricity plants in Nigeria are underutilized or not functioning at all. Numerous reasons could be sighted as responsible for the underutilization of these plants. Some of which are (1) scarcity of relevant manpower for adequate maintenance and general consumer indiscipline; (2) lack of essential spare parts for maintenance of the plants; (3) absence of local manufacturing capabilities;(4) lack of systematic studies of distribution networks to reduce the extraordinary losses that usually accompany haphazard system expansion; and (5) inability to convert gas flares to a source of electricity [33].

The inefficiency as well as the inadequate facilities to boost electricity supply also have been major causes of the increasing gap between the demand and the supply of electricity. This could be due to the fact that there are only 14 generating stations in Nigeria (3 hydro and 11 thermal stations). Out of the approximated 8,039 MW of installed capacity in Nigeria, not more than 4,500 MW is ever produced. This is due to poor maintenance, fluctuation in water levels powering the hydro plants, and the loss of electricity in transmission. It could also be due to the 80-MW export of electricity each to the republic of Niger and Benin. 'Apart from serving as a pillar of wealth creation in Nigeria, electricity is also the nucleus of operations and subsequently the engine of growth for all sectors of the economy' [34]. It has been indirectly re-echoed that electricity consumption is positively related to economic growth and that the former is a causal factor of the latter. This means that electricity consumption has diverse impacts on a range of socioeconomic activities and consequentially the living standards of Nigerians.

Notwithstanding the above pitfalls that had rendered public electricity supply in Nigeria unreliable and inefficient, the trend of its utilization has grown significantly over the past years. Figure 1 shows the total electricity consumption in megawatts per hour and the various sectorial decompositions. Electricity utilization by the industrial sector has been fairly static because of the unreliable nature of the public electricity supply system in the country. Thus, many companies have resolved to provide their own power-generating sets as sources of electricity, leading to huge transfer costs on their products and services.

Studies and experiences have shown that power generation in the country has been dismal and unable to compare with what has been obtained in smaller African countries. Manufacturers Association of Nigeria (MAN) gave the following performance indicators in Table 4 for Nigeria's electricity sector compared with those of some other countries [28]. The data for some Southern Africa Development Community (SADC) countries such as Botswana and South Africa are comparable to those of the USA and France. The performance of the Nigerian power sector on the International Best Practices comparative rating is disgraceful. Perhaps, no other sector feels it as much as the manufacturing industrial sector wherein some notable international companies and organizations are on self-generated electricity $24 \mathrm{~h}$ /day for the 365 days

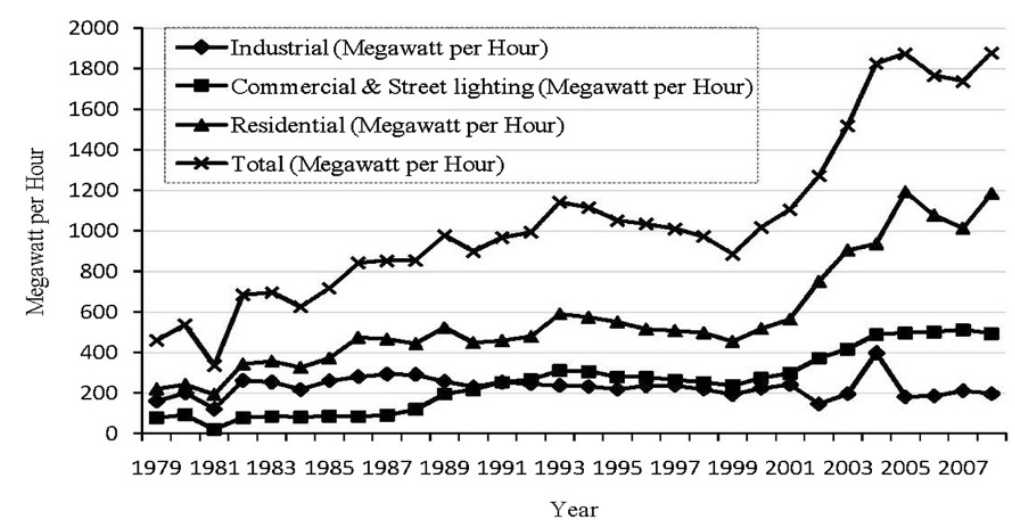

Figure 1 Electricity consumption pattern in Nigeria. Adapted from CBN [35]. 
Table 4 Power supply reliability indices (international best practices)

\begin{tabular}{llllll}
\hline Index & USA & Singapore & France & $\begin{array}{l}\text { Nigeria } \\
\text { (NEPA } \\
\text { data) }\end{array}$ & $\begin{array}{l}\text { Nigeria } \\
\text { (MAN } \\
\text { study) }\end{array}$ \\
\hline $\mathrm{SAIDI}^{\mathrm{a}}(\mathrm{min})$ & 88 & 1.5 & 52 & 900 & $\geq 60,000$ \\
$\mathrm{SAIFI}^{\mathrm{b}}($ number/year & 1.5 & $\mathrm{NA}$ & $\mathrm{NA}$ & 5 & $\geq 600$ \\
$\mathrm{CAIDI}^{\mathrm{c}}(\mathrm{h})$ & 0 & $\mathrm{NA}$ & 0 & 9 & 15 \\
$\mathrm{ASAl}^{\mathrm{d}}$ & 1 & 1 & 1 & $\mathrm{NA}$ & $\leq 0.4$
\end{tabular}

${ }^{a}$ SAIDI, System average international duration index - Annual average total duration of power interruption to a consumer, in minutes; ${ }^{\mathrm{b}} \mathrm{SAIFI}$, System average interruption frequency index - Average number of interruptions of supply that a consumer experiences annually; ${ }^{\mathrm{C}} \mathrm{CAIDI}$, Consumer average interruption duration index - Average duration of an interruption of supply for a consumer who experiences the interruption on an annual basis, in hours; ${ }^{\mathrm{d}} \mathrm{ASAl}$, Average service availability index - Ratio of (Consumer hours service availability)/(Consumer hours service demanded). Adapted from Fagbenle et al. [28].

of each year, as confirmed by the United Nations Industrial Development Organization in 2009 [36]. The survey showed that, on average, manufacturers generated about $72 \%$ of the total power required to run their factories.

\section{The Nigerian energy challenge}

Nigeria's energy need is on the increase, and its increasing population is not adequately considered in the energy development program. The present urban-centered energy policy is deplorable, as cases of rural and sub-rural energy demand and supply do not reach the center stage of the country's energy development policy. People in rural areas depend on burning wood and traditional biomass for their energy needs, causing great deforestation, emitting greenhouse gases, and polluting the environment, thus creating global warming and environmental concerns. The main task has been to supply energy to the cities and various places of industrialization, thereby creating an energy imbalance within the country's socioeconomic and political landscapes. Comparing the present and ever increasing population with the total capacity of the available power stations reveals that Nigeria is not able to meet the energy needs of the people. The rural dwellers still lack electric power [37].

The nature of Nigeria's energy crises can be characterized by two key factors. The first concerns the recurrent severe shortages of the petroleum product market of which kerosene and diesel are the most prominent. Nigeria has five domestic refineries owned by the government with a capacity to process 450,000 barrels of oil per day, yet imports constitute more than $75 \%$ of petroleum product requirements. The state-owned refineries have hardly operated above a $40 \%$ capacity utilization rate for any extended period of time in the past two decades. The gasoline market is much better supplied than kerosene and diesel because of its higher political profile. This factor explains why the government has embarked on large import volumes to remedy domestic shortages of the product. According to the Minister for Energy, the subsidy to support the imports of gasoline alone will be in the range of 700 to 800 billion naira in 2008 [38]. The weaker political pressures exerted by the consumers of kerosene (the poor and low middle class) and diesel (industrial sector) on the government and the constraints on public financing of large-scale imports of these products, as in the case of gasoline, largely explain their more severe and persistent market shortages [39].

The second dimension of Nigeria's energy crises is exemplified by such indicators as electricity blackouts, brownouts, and pervasive reliance on self-generated electricity. This development has occurred despite abundant energy resources in Nigeria. The electricity market, dominated on the supply side by the state-owned PHCN, formerly called NEPA, has been incapable of providing minimum acceptable international standards of electricity service reliability, accessibility, and availability for the past three decades [40]. The nature of this poor record in electricity supply is apparent in the trend in transmission and distribution losses shown in Figure 2. The double-digit transmission and distribution losses are extremely large by international standards and are among the highest in the world. The system losses are five to

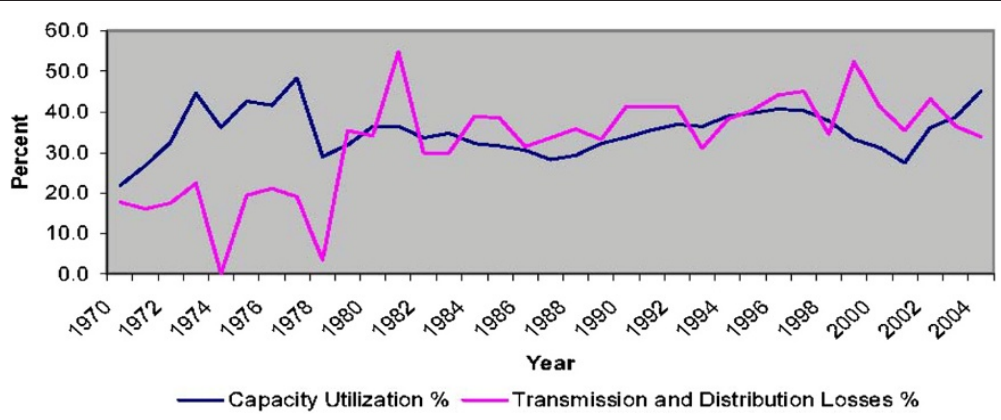

Figure 2 Indicators of the electricity crisis in Nigeria from 1970 to 2004. Adapted from Iwayemi [38]. 
six times higher than those in well-run power systems. The high level of power losses and the significant illegal access to the public power supply are indicative of the crisis in the industry.

Though the peak electricity demand has been less than half of the installed capacity in the past decade, load shedding occurs regularly. Power outages in the manufacturing sector provide another dimension to the crisis. In 2004, the major manufacturing firms experienced 316 outages. This increased by $26 \%$ in 2005 , followed by an explosive 43\% increase between 2006 and 2007. Though no published data exist, the near collapse of the generating system to far below 2,000 MW for prolonged periods of time suggests a reason for the number of outages in 2008 to be very high. This poor service delivery has rendered public supply a standby source as many consumers who cannot afford irregular and poor quality service substitute more expensive captive supply alternatives to minimize the negative consequences of power supply interruptions on their production activities and profitability. An estimated $20 \%$ of the investment into industrial projects is allocated to alternative sources of electricity supply [3].

In summary, the causal factors in Nigeria's energy crisis include the following:

- Prevalence of a regime of price control.

- Weak concern for cost recovery and lack of adequate economic incentives to induce the stateowned companies (NNPC and PHCN) to engage in efficient production and investment behavior. This seems apparent in the existence of large input and output subsidies.

- Multiplicity of economic and noneconomic objectives without proper identification of the tradeoffs among these different objectives. This is implicit in its pricing policies in both electricity and petroleum products markets.

- Institutional and governance failures which induced gross distortions and inefficiency in production, investment choices and high costs of operation, low return on investment, and expensive delays along with cost overruns in the state energy enterprises.

\section{Energy demand projection}

There is an increasing demand for fuel energy due to the increase in economic development and civilization all over the world. Industry is one of the most important energy-consuming sectors in the world. According to Mitchel [41], energy is essential to our way of life. It provides us with comfort, transportation, and the ability to produce food and material goods. Historically, energy consumption has been directly related to the gross national product, which is a measure of the market value of the total national output of goods and services [42].

According to Sambo et al. [43], population is a major driver of energy demand, while its most important determinant is the level of economic activity and its structure measured by the total gross domestic product (GDP) alongside the various sectors and sub-sectors of the economy. Population projection of Nigeria was expected to grow from 115.22 million in 2000 to 281.81 million by 2030 at an average annual rate of $2.86 \%$ between 2000 and 2030.

Based on the models developed by the ECN, the country's energy demand was analyzed for the period from 2000 to 2030 with the use of the Model for the Analysis of the Energy Demand (MAED) and the Wien Automatic System Planning (WASP) package (Table 5). It can be said that the energy demand of Nigeria will be approximately 2.5-, 3-, 3.5-, and 4.5-fold between the years 2000 and 2015 and approximately 8-, 13-, 17-, and 22.5fold between the years 2000 and 2030 based on a 7\% (reference), 10\% (high growth), 11.5\% (optimistic), and $13 \%$ (optimistic) GDP growth rate per annum, respectively. This increase in the energy demand is due to the high level of economic activities expected in Nigeria as measured by the total GDP.

The trends of the projected energy demand are shown in Figure 3. In 2005, the total energy demand based on a $10 \%$ GDP growth rate revealed that the household segment had the largest share of all the sectors. The sectorial energy demands in the 2030 plan period, however, showed the highest growth rates for the industrial, followed by the services, household, and transport sectors in that order (Table 6). The electricity demand (extracted from the total energy demand) shows an increasing trend from the base year 2005 to 2030 in the four adopted growth scenarios, respectively, as shown in Figure 4, indicating a high economic growth rate leading to a substantial increase in the electricity demand. The energy consumed over the years shows a decreasing trend with an increasing population, necessitating a corresponding increase in the energy output. Hence, the country's large energy efficiency potential needs to be exploited (Table 7). In 2007, the total primary energy consumed was 11.4 million tons of oil equivalent (MTOE) with petroleum products having the largest

Table 5 Total projected energy demand (MTOE)

\begin{tabular}{lllllll}
\hline Scenario & $\mathbf{2 0 0 0}$ & $\mathbf{2 0 1 0}$ & $\mathbf{2 0 1 5}$ & $\mathbf{2 0 2 0}$ & $\mathbf{2 0 2 5}$ & $\mathbf{2 0 3 0}$ \\
\hline Reference (7\%) & 32.01 & 51.40 & 79.36 & 118.14 & 169.18 & 245.19 \\
High growth (10\%) & 32.01 & 56.18 & 94.18 & 190.73 & 259.19 & 414.52 \\
Optimistic (11.5\%) & 32.01 & 56.18 & 108.57 & 245.97 & 331.32 & 553.26 \\
Optimistic (13\%) & 32.01 & 72.81 & 148.97 & 312.61 & 429.11 & 715.70 \\
\hline
\end{tabular}

Adapted from ECN [44]. 


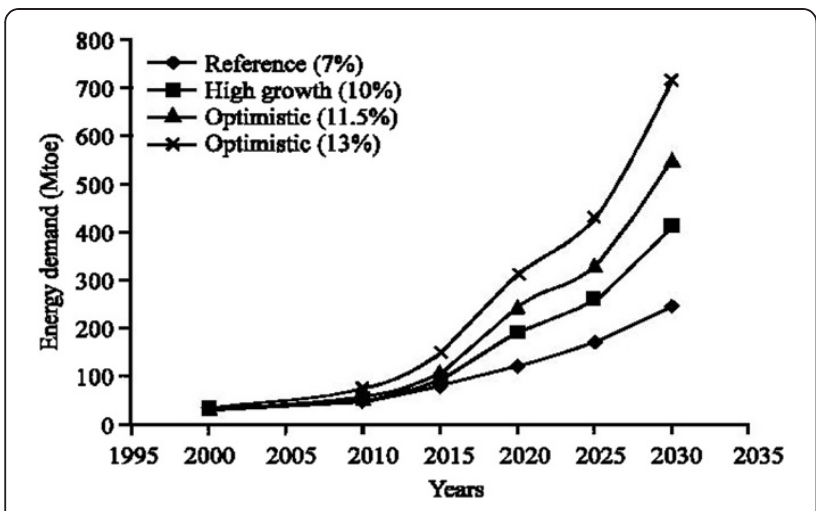

Figure 3 Graph showing the projected electricity demand between 2000 and 2030 .

share of $67.3 \%$ of the total consumption, amounting to a total average consumption of $78.7 \%$ between 2002 and 2007. This level of consumption was followed by that of hydropower at $23.9 \%$, natural gas at $8.7 \%$, and coal at $0.05 \%$ with their respective total average consumption standing at $16.08 \%, 5.17 \%$, and $0.04 \%$ for the period from 2002 to 2007 as shown in Table 8. Flaring adversely reduced the maximum contribution of natural gas to the total energy consumption mix in spite of its abundance in the country as most of the oil fields lack appropriate infrastructure for gas production. The general Niger Delta security issue (bunkering, sabotage, etc.) have also weakened most of the oil and gas projects [45].

Throughout the world, electricity is the most widely used and desirable form of energy. It is a basic requirement for economic development, national development, meeting the Millennium Development Goals (MDGs), and for an adequate standard of living. As a country's population grows and its economy expands, its demand for electrical energy multiplies. If this demand is not met adequately, a shortage in supply occurs. This shortage can assume crisis proportions and possibly affect achieving sustainable energy development.

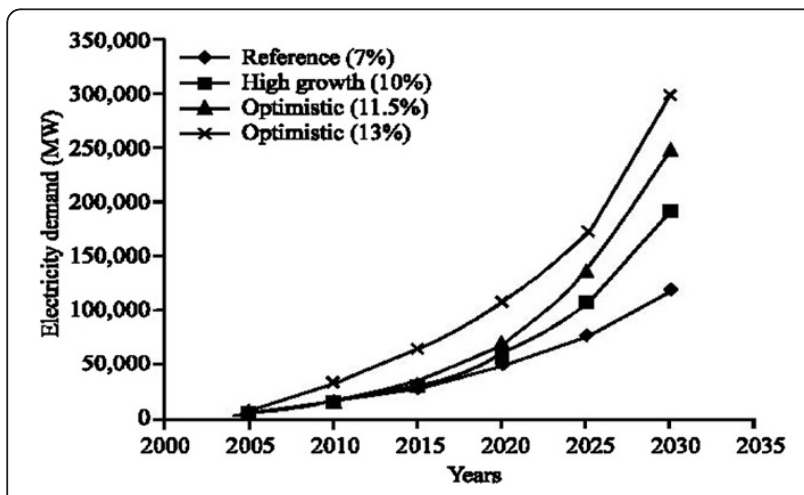

Figure 4 Graph showing the projected electricity demand between 2005 and 2030.
Table 6 Total energy demand based on a $10 \%$ GDP growth rate (MTOE)

\begin{tabular}{lrrrrrrrc}
\hline Item & $\mathbf{2 0 0 5}$ & $\mathbf{2 0 1 0}$ & $\mathbf{2 0 1 5}$ & $\mathbf{2 0 2 0}$ & $\mathbf{2 0 2 5}$ & $\mathbf{2 0 3 0}$ & $\begin{array}{c}\text { Average } \\
\text { growth } \\
\text { rate (\%) }\end{array}$ \\
\hline Industry & 8.08 & 12.59 & 26.03 & 39.47 & 92.34 & 145.21 & 16.2 \\
Transport & 11.70 & 13.48 & 16.59 & 19.70 & 26.53 & 33.36 & 4.7 \\
Household & 18.82 & 22.42 & 28.01 & 33.60 & 33.94 & 34.27 & 2.6 \\
Services & 6.43 & 8.38 & 12.14 & 15.89 & 26.95 & 38.00 & 8.7 \\
Total & 45.01 & 56.87 & 82.77 & 108.66 & 179.75 & 250.84 & 8.3 \\
\hline
\end{tabular}

Adapted from ECN [46].

The electric power capacity demand by projection in Nigeria would be approximately 3.5-fold between 2010 and 2020 and 7.5-fold between 2010 and 2030, respectively, at a growth rate of $7 \%$, while the projected supply by fuel mix shows a similar trend with the demand at both growth rates of $7 \%$ and $13 \%$ (Table 9). There is a wide disparity in the energy demand to the supply ratio in Nigeria both in the present and the future. This necessitates an urgent need for alternative energy sources and efficient energy usage in order to avert looming energy crises.

These projections for continued rapid energy growth imply some severe problems for the future resource depletion, energy degradation, associated environmental problems, fuel shortage, etc. Indeed, many of these problems are already happening; thus, energy conservation is concerned with ways to reduce energy demand, but yet achieve the same objective as before.

To achieve its objective of sustainable development, Nigeria needs to substantially increase the supply of modern affordable energy services to all its citizens while, at the same time, maintaining environmental integrity and social cohesion. In addition, a robust mix of energy sources (fossil and renewable), combined with an improved end-use efficiency, will almost certainly be required to meet the growing demand for energy services in the country. Technological development, decentralized non-grid networks, diversity of energy-supply

Table 7 Per capita primary energy consumption in Nigeria

\begin{tabular}{llll}
\hline Year & $\begin{array}{l}\text { Energy } \\
\text { consumed } \\
\text { (MTOE) }\end{array}$ & $\begin{array}{l}\text { Population } \\
\text { (million) }\end{array}$ & $\begin{array}{l}\text { Per capita energy } \\
\text { consumption } \\
\text { (TOE/capita) }\end{array}$ \\
\hline 2002 & 18.783 & 122.365 & 0.153 \\
2003 & 19.106 & 126.153 & 0.151 \\
2004 & 16.267 & 129.927 & 0.125 \\
2005 & 17.707 & 133.702 & 0.132 \\
2006 & 12.421 & 140.003 & 0.089 \\
2007 & 11.387 & 144.203 & 0.097 \\
\hline
\end{tabular}

Adapted from CBN and NBS $[32,47,48]$. 
Table 8 Commercial primary energy consumption by type (average percentage of total)

\begin{tabular}{lrrrrrrr}
\hline Type & $\mathbf{2 0 0 2}$ & $\mathbf{2 0 0 3}$ & $\mathbf{2 0 0 4}$ & $\mathbf{2 0 0 5}$ & $\mathbf{2 0 0 6}$ & $\mathbf{2 0 0 7}$ & Average \\
\hline Coal & 0.03 & 0.03 & 0.03 & 0.03 & 0.05 & 0.05 & 0.04 \\
Hydro & 11.93 & 14.20 & 17.39 & 12.04 & 17.03 & 23.90 & 16.08 \\
Natural gas & 2.84 & 1.9 & 4.54 & 5.5 & 7.52 & 8.73 & 5.17 \\
Petroleum products & 85.20 & 83.87 & 78.04 & 82.45 & 75.44 & 67.32 & 78.71 \\
\hline
\end{tabular}

Adapted from CBN [32,49].

systems, and affordable energy services are imperative to meeting the future demand.

\section{The role of renewable energy technologies in sustainable} development

Renewable energy has an important role to play in meeting the future energy needs in both rural and urban areas [50]. The development and utilization of renewable energy should be given a high priority, especially in the light of increased awareness of the adverse environmental impacts of fossil-based generation. The need for sustainable energy is rapidly increasing in the world. A widespread use of renewable energy is important for achieving sustainability in the energy sectors in both developing and industrialized countries.

Nigeria is blessed with a large amount of renewable natural resources (Table 1), which, when fully developed and utilized, will lead to poverty reduction and sustainable development.

Renewable energy resources and technologies are a key component of sustainable development for the following primary reasons:

- They generally cause less environmental impact than other energy sources. The implementation of renewable energy technologies will help to address the environmental concerns that emerged due to greenhouse gas emissions such as carbon dioxide
$\left(\mathrm{CO}_{2}\right)$, oxides of nitrogen $\left(\mathrm{NO}_{\mathrm{x}}\right)$, oxides of sulfur $\left(\mathrm{SO}_{\mathrm{x}}\right)$, and particulate matters as a result of power generation from oil, natural gas, and coal. A variety of renewable energy resources provide a flexible array of options for their use.

- They cannot be depleted. If used carefully in appropriate applications, renewable energy resources can provide a reliable and sustainable supply of energy almost indefinitely. In contrast, fossil fuel resources are diminished by extraction and consumption.

- They favor system decentralization and local solutions that are somewhat independent of the national network, thus enhancing the flexibility of the system and providing economic benefits to small isolated populations.

To seize the opportunities presented by renewable energy resources in sustainable development, Nigeria needs to establish renewable energy markets and gradually develop experience with renewable energy technologies. The barriers and constraints to the diffusion of renewable energy should be overcome. A legal, administrative, and financing infrastructure should be established to facilitate planning and application of renewable energy projects. Government must play a useful role in promoting renewable energy technologies by initiating surveys and studies to establish their potential in both urban and rural areas.

Because renewable energies are constantly being replenished from natural resources, they have security of supply, unlike fossil fuels, which are negotiated on the international market and subject to international competition, sometimes even resulting in wars and shortages. They have important advantages, which could be stated as follows:

- Their rate of use does not affect their availability in the future; thus, they are inexhaustible.

Table 9 Electric power capacity in Nigeria

\begin{tabular}{|c|c|c|c|c|c|c|c|c|c|c|c|c|}
\hline \multicolumn{13}{|c|}{ Electric power demand } \\
\hline \multirow[b]{3}{*}{ Fuel type } & \multicolumn{4}{|c|}{2010} & \multicolumn{4}{|c|}{2020} & \multicolumn{4}{|c|}{2030} \\
\hline & \multicolumn{2}{|c|}{ Demand (MW\%) } & \multicolumn{2}{|c|}{ Supply (MW\%) } & \multicolumn{2}{|c|}{ Demand (MW\%) } & \multicolumn{2}{|c|}{ Supply (MW\%) } & \multicolumn{2}{|c|}{ Demand (MW\%) } & \multicolumn{2}{|c|}{ Supply (MW \%) } \\
\hline & 7 & 13 & 7 & 13 & 7 & 13 & 7 & 13 & 7 & 13 & 7 & 13 \\
\hline Coal & & & 0 & 0 & & & 6.515 & 16.913 & & & 15.815 & 63.896 \\
\hline Gas & & & 13.555 & 31.935 & & & 37.733 & 78.717 & & & 85.585 & 192.895 \\
\hline Hydro & & & 3.702 & 3.902 & & & 6.479 & 6.749 & & & 11.479 & 11.479 \\
\hline Nuclear & & & 0 & 0 & & & 3.530 & 11.005 & & & 11.872 & 36.891 \\
\hline Small-hydro & & & 40 & 208 & & & 140 & 1.000 & & & 701 & 2.353 \\
\hline Solar & & & 5 & 30 & & & 34 & 750 & & & 302 & 4.610 \\
\hline Wind & & & 0 & 500 & & & 1.471 & 3.791 & & & 5.369 & 15.567 \\
\hline Total & 15.730 & 33.250 & 17.303 & 36.576 & 50.820 & 107.600 & 55.903 & 118.836 & 119.200 & 297.900 & 131.122 & 327.690 \\
\hline
\end{tabular}

Supply by fuel mix and demand for $7 \%$ and $13 \%$ GDP growth. Adapted from ECN $[44,46]$. 
- The resources are generally well distributed all over the world, even though wide spatial and temporal variations occur. Thus, all regions of the world have reasonable access to one or more forms of renewable energy supply.

- They are clean and pollution-free and are therefore a sustainable natural form of energy.

- They can be cheaply and continuously harvested and are therefore a sustainable source of energy.

Unlike the nuclear and fossil fuels plants which belong to big companies, governments, or state-owned enterprises, renewable energy can be set up in small units and is therefore suitable for community management and ownership. In this way, the returns from renewable energy projects can be kept in the community. In Nigeria, this has particular relevance since the electricity grid does not extend to remote areas, and it is prohibitively expensive to do so. This presents a unique opportunity to construct power plants closer to where they are actually needed. In this way, much needed income, skill transfer, and manufacturing opportunities for small businesses would be injected into rural communities.

\section{Energy and sustainable development in Nigeria}

Sustainable energy involves the provision of energy services in a sustainable manner, which in turn necessitates that energy services be provided for all people in ways that, now and in the future, are sufficient to provide the basic necessities, affordable, not detrimental to the environment, and acceptable to communities and people [51-53]. Linkages between sustainable energy and factors such as efficiency and economic growth have been investigated [54].

The energy sector plays a pivotal role in attempts to achieve sustainable development, balancing economic and social developments with environmental protection (encapsulated in the 'strap line' for the 2002 Johannesburg World Summit on Sustainable Development of 'people, planet, and prosperity'). Energy is central to practically all aspects of sustainable development. Energy is central to the economy because it drives all economic activities. This characterization of energy directs our attention to its sources in nature, to activities that convert and reconvert this energy, and finally to activities that use the energy to produce goods and services and household consumption. Traditionally, energy is treated as an intermediate input in the production process. This treatment of energy's role understates its importance and contribution to development. All economic activities and processes require some form of energy. This effectively makes energy a critical primary factor of production. Given the state of technological advancement in the economy, capital and labor perform supporting roles in converting, directing, and amplifying energy to produce goods and services needed for growth and poverty reduction [3].

Energy services are essential ingredients of all three pillars of sustainable development - economic, social, and environmental. Economies that have replaced human and animal labor with more convenient and efficient sources of energy and technology are also the ones that have grown fastest. No country in modern times has succeeded in substantially reducing poverty without adequately increasing the provision and use of energy to make material progress [55]. Indeed, by not ensuring a minimum access to energy services for a broad segment of the population, economic development of developing countries such as Nigeria beyond the level of subsistence has proven to be a real challenge.

At the national level, energy propels economic development by serving as the launch pad for industrial growth and, via transport and communications, providing access to international markets and trade. Reliable, efficient, and competitively priced energy supplies also attract foreign investment - a very important factor in boosting economic growth in recent times. At the local level, energy facilitates economic development by improving productivity and enabling local income generation through improved agricultural development (irrigation, crop processing, storage, and transport to market) and through non-farm employment, including micro-enterprise development. As an indicator of local recognition of the importance of energy for businesses, Nigerian manufacturers, who were asked to rank the constraints on their firms' activities, identified power breakdowns, and voltage fluctuations as their top two problems [46]. Recent developments in Ghana's energy sector support this point [56].

Energy has also strong and important links to the environment. Many energy sources are drawn directly from the environment, requiring a sound management for these sources to be sustainable. Furthermore, energy use affects the environment. Emissions from fossil fuels, for example, reach beyond the local and national levels to affect the global environment and contribute to climate change. The poorest people often live in the most ecologically sensitive and vulnerable physical locations. These areas may be the most affected by the predictable effects of climate change such as an increased frequency of extreme events, for example floods, drought, rising sea levels, and melting ice caps. The risks facing poor people are often increased by the unsustainable use of biomass resources [3].

The connection between energy, the environment, and sustainable development is worth highlighting. Energy supply and use are related to climate change as well as such environmental concerns as air pollution, ozone 
depletion, forest destruction, and emissions of radioactive substances. These issues must be addressed if society is to develop while maintaining a healthy and clean environment. Ideally, a society seeking sustainable development should use only energy resources which have no environmental impact. However, since all energy resources lead to some environmental impact, an improved efficiency and environmental stewardship can help overcome many of the concerns regarding the limitations imposed on sustainable development by environmental emissions and their negative impacts [55].

Energy is directly linked to the broader concept of sustainability and affects most of civilization. That is particularly evident since energy resources drive much if not most of the world's economic activity, in virtually all economic sectors. Also, energy resources, whether carbon-based or renewable, are obtained from the environment, and wastes from energy processes (production, transport, storage, utilization) are typically released to the environment. Given the intimate ties between energy and the key components of sustainable development, the attainment of energy sustainability is being increasingly recognized as a critical aspect of achieving sustainable development [55].

Use of renewable natural resources, combined with efficient supply and use of fossil fuels with cleaner technologies, can help reduce the environmental effects of energy use and help Nigeria replacing the existing, inefficient fossil fuel technologies that pollute the environment.

As a complementary measure, careful management of energy resources is important to promote economic growth, protect ecosystems and provide sustainable natural resources.

Thus, energy sustainability is considered to involve the sustainable use of energy in the overall energy system. This system includes processes and technologies for the harvesting of energy sources, their conversion to useful energy forms, to provide energy services such as operating communications systems, lighting buildings, and cooking [57].

The reform of the energy sector is critical to sustainable development in Nigeria. This includes reviewing and reforming subsidies, establishing credible regulatory frameworks, developing policy environments through regulatory interventions, and creating market-based approaches such as emission trading [58]. Globally, countries are developing strategies and policies to enable a sustainable development of their energy resources, thus contributing to fuel economic and social developments, while reducing air pollution and greenhouse gas emissions.

The energy sector is very strategic to the development of the Nigerian economy. In addition to its macroeconomic importance, it has major roles to play in reducing poverty, improving productivity, and enhancing the general quality of life. If Nigeria is to take the path of sustainable energy, it is important to accurately and technically model the energy demand and supply scenarios and their impacts on the economy, resources, and society along with the environment, for both medium and long terms. From such analyses, we can derive information that is vital for policy construction and investment [59].

\section{Energy efficiency and energy conservation in sustainable development}

Energy efficiency means an improvement in practices and products that reduce the energy necessary to provide services. Energy efficiency products essentially help to do more work with less energy [60]. Energy efficiency is also defined as essentially using less energy to provide the same service [55]. In this sense, energy efficiency can also be thought of as a supply of resource - often considered an important, cost-effective supply option. Investment into energy efficiency can provide additional economic value by preserving the resource base (especially combined with pollution prevention technologies) and mitigating environmental problems.

Energy efficiency (EE) improvements have multiple advantages, such as the efficient exploitation of natural resources, the reduction in air pollution levels, and lower spending by the consumers on energy-related expenditure. Investments in EE result in long-term benefits, such as reduced energy consumption, local environmental enhancement, and overall economic development. Energy use has environmental impacts, regardless of the source or mechanism. For example, hydroelectric projects affect their local ecological systems and displace long-standing social systems. Fossil fuel power creates pollution in the extraction, transportation, and combustion of its raw materials. The long-term storage of waste products of the nuclear power industry is an issue to be resolved. Cost-effective energy efficiency is the ultimate multiple pollutant reduction strategy [61].

In Nigeria, a lot of energy is wasted because households, public and private offices, as well as industries use more energy than is actually necessary to fulfill their needs. One of the reasons is that they use outdated and inefficient equipment and production processes. Unwholesome practices also lead to energy wastage.

In Nigeria, the need for energy is exceeding its supply. In view of these circumstances, primary energy conservation, rationalization, and efficient use are immediate needs. Getting all the possible energy from the fuel into the working fluid is the goal of efficient equipment operations. This leads to a higher productivity and saves not only money, but also influences the safety and life of the equipment and reduces pollution [62]. Steps taken to minimize energy consumption, or to use the energy 
more effectively, are steps in the right direction to preserve the global environment. Energy conservation measures or recommendations are often referred to more positively as opportunities. Two primary criteria for applying energy conservation are that it is easy to implement and that its payback is brief. Ease of implementation and duration of payback period have been used to classify Energy conservation opportunities into three general categories for use: in maintenance and operation measures, in process improvement projects, and in large capital projects [61].

Energy conservation and energy efficiency are separate but related concepts. Energy efficiency is achieved when energy intensity in a specific product, process, or area of production or consumption is reduced without affecting output, consumption, or comfort levels. Promotion of energy efficiency will contribute to energy conservation and is therefore an integral part of energy conservation promotional policies [63].

Energy efficiency encompasses conserving a scarce resource; improving the technical efficiency of energy conversion, generation, transmission and end-use devices; substituting more expensive fuels with cheaper ones; and reducing or reversing the negative impact of energy production and consumption activities on the environment. Energy conservation is a tangible resource by itself that competes economically with contemporary energy supply options. In addition to this, it offers a practical means of achieving four goals that should be of high priority in any nation that desires quick and sustainable economic growth and development. These are economic competitiveness, utilization of scarce capital for development, environmental quality, and energy security. It enhances the international competitiveness of the industries in the world markets by reducing the cost of production. It optimizes the use of capital resources by directing lesser amounts of money in conservation investment as compared with capital-intensive energy supply options. It protects the environment in the short run by reducing pollution and in the long run by reducing the scope of global climate change. It strengthens the security of supply through a lesser demand and a lesser dependence on petroleum product imports. No energy supply option may be able to provide all these benefits. Energy conservation is a decentralized issue and is largely dependent on individual, distinct decisions of energy supply, which are highly centralized. The housewife, the car driver, the housing developer, the house owner, the boiler operator in industry, and every other individual who consumes energy in some form or another are required to participate in energy-saving measures. It calls for a collective endeavor and is dependent upon the actions of people in diverse fields although the people involved may not be sufficiently informed or motivated to conserve energy [64].

\section{Renewable energy and energy efficiency as climate change mitigation strategies}

The Inter-government Panel on Climate Change (IPCC), a body set up in 1988 by the World Meteorological Organization and the United Nations Environmental Programme to provide authoritative information about the climate change phenomenon, asserts that the warming of the last 100 years was unusual and unlikely to be natural in origin [58]. The IPCC has attributed the warming of at least the second half of the century to an increase in the emission of greenhouse gases into the atmosphere. Human activity is largely responsible for the emission of these gases into the atmosphere: $\mathrm{CO}_{2}$ is produced by the burning of fossil fuels (coals, oil, gas) as well as by land-use activities such as deforestation; methane is produced by cattle, rice agriculture, fossil fuel use, and landfills; and nitrous oxide is produced by the chemical industry, cattle feed lots, and agricultural soils. As humans have increased their levels of production and consumption, greenhouse gas emissions have also increased; since 1750, at the time of the industrial revolution, $\mathrm{CO}_{2}$ emission has increased by $31 \%$, methane by $15 \%$, and nitrous oxide by $17 \%$. Moreover, the emissions of these gases continue to rise steadily [65].

The Clean Development Mechanism (CDM) was integrated to the Kyoto Protocol as the United Nations Framework Convention on Climate Change [66]. CDM projects allow investment by entities from industrialized countries into projects in developing countries. In return for this investment, carbon credits (in this case, certified emission reductions) are received by the investor in the industrialized country. This enables the industrialized country to meet its emission reduction targets given by the Kyoto Protocol more cost-effectively, while promoting sustainable development in developing countries. CDM projects may also be unilateral, i.e., they take place in the developing country without a project partner from an industrialized nation.

Investment into clean energy facilities is recognized as the best way to increase the participation of Nigerian proponents in the CDM process and hence the global carbon market. Clean energy investment is defined as follows: investment into an energy supply and utilization system that provides the required energy with minimal negative environmental and social consequences [67]. Investment into clean energy systems can also be viewed as an investment into energy sources and technologies that are significantly less environmentally damaging than in the status quo case. Investment into clean energy systems provides the most effective and optimally efficient path to an increased CDM participation in Nigeria and hence an effective participation in the global carbon market. 
The salient characteristics of clean energy investment are as follows:

- The resulting system results in little or no emissions of obnoxious gases and particulates;

- The clean energy technologies have a carbon footprint that is much lower than the baseline emission scenario;

- The technology is accessible, and the required investment is available for adoption in developing countries like Nigeria;

- The implementation of the clean energy technology will contribute to sustainability.

Energy efficiency and renewable energy technologies are prominent in most sustainable development programs, for example, the Agenda 21 [68]. According to the Intergovernmental Panel on Climate Change (IPCC), the second assessment report, the stabilization of atmospheric greenhouse gas concentrations at levels that will prevent serious interference with the climate system can only be achieved by dramatically increasing the implementation of renewable energy. In one IPCC scenario, in which greenhouse gases are stabilized by the year 2050, the share of renewable energy in the global energy balance must increase tenfold from the current level. In developing countries, the required increase is even more dramatic, estimated at 20-fold between 1990 and 2050. Further improvements in energy efficiency and energy conservation can reduce emissions in the shorter term, thus 'buying time' for the required changes in energy production [69].

Nigeria is one of the highest emitters of greenhouse gases in Africa. The practice of flaring gas by the oil companies operating in Nigeria has been a major means through which greenhouse gases are released into the atmosphere. Carbon dioxide emissions in this area are among the highest in the world [70]. Some 45.8 billion $\mathrm{kW}$ of heat are discharged into the atmosphere of the Niger Delta from flaring 1.8 billion $\mathrm{ft}^{3}$ of gas every day [58]. Gas flaring has raised temperatures and rendered large areas uninhabitable. Between 1970 and 1986, a total of about 125.5 million $\mathrm{m}^{3}$ of gas was produced in the Niger Delta region, about 102.3 (81.7\%) million $\mathrm{m}^{3}$ were flared, while only 2.6 million $\mathrm{m}^{3}$ were used as fuel by oil-producing companies and about 14.6 million $\mathrm{m}^{3}$ were sold to other consumers $[71,72]$. The use of renewable energy sources will reduce the over dependence on the burning of fossil fuel. Moreover, instead of flaring gas in Nigeria, the gases can be converted to methanol and used as a fuel for both domestic and industrial use. With good energy efficiency practices and products, the burning of fossil fuel for energy will be greatly minimized.

\section{Conclusions}

From the energy outlook of Nigeria, it is very clear that the energy demand is very high and is increasing geometrically while the supply remains inadequate, insecure, and irregular and is decreasing with time; the mix has hitherto been dominated by fossil resources which are fast being depleted apart from being environmentally non-friendly. The energy supply mix must thus be diversified through installing an appropriate infrastructure and creating full awareness to promote and develop the abundant renewable energy resources present in the country as well as to enhance the security of supply.

There is clear evidence that Nigeria is blessed with abundant resources of fossil fuels as well as renewable energy resources. The major challenge is an inefficient usage of energy in the country. As a result, there is an urgent need to encourage the evolvement of an energy mix that will emphasize the conservation of petroleum resources in such a manner enabling their continued exportation for foreign earnings for as many years as possible.

The opportunities for conserving energy in our various sectors - office building and residential areas, manufacturing industries, transportation, electricity generation and distribution, and electricity equipment and appliances - were presented in this work. The various areas where savings in energy can be made have also been identified. Several guidelines and measures have been suggested to conserve energy in these areas, and if the guidelines and measures are strictly adhered to, then substantive savings in energy will be carried out.

In this study, four economic growth scenarios were dealt with in the review of the energy requirements. These are the reference scenarios of a $7 \%$ total GDP growth rate that will ensure the MDGs of reducing poverty by $50 \%$ of the 2,000 value by 2015 . The high growth scenario of a $10 \%$ GDP growth rate in the attempt to eradicate poverty by 2030 and the optimistic scenarios of $11.5 \%$ and 13\% GDP growth rates that will further increase the rate of economic development.

In order to ensure the sustainability of energy supply and subsequently the sustainable economic development of the country, the government has to intensify the further implementation of renewable energy and energy efficiency programs. As observed in quite a number of successful countries promoting renewable energy, such as Germany, Denmark, and Japan, a strong and long-term commitment from the government is crucial in implementing any kind of policies which will lead to the development of renewable energies, in particular, and a sustainable development, in general. 


\section{Recommendations}

In this study, it is established that renewable energy and energy efficiency are two components that should go together to achieve sustainable development in Nigeria. The need to conserve the present energy generated in the country using energy-efficient products and the appropriate practices is essential for sustainable development. Therefore, it is recommended that the country should do the following:

- Develop policies on energy efficiency and integrate them into the current energy policies. A comprehensive and coherent energy policy is essential in guiding the citizens towards an efficient usage of its energy resources.

- Promote energy-efficient products and appropriate practices at the side of the end users and energy generation.

- Create awareness on renewable energy and energy efficiency.

- Establish an agency to promote the use of energyefficient products and ensure the appropriate practices.

- Develop and imbibe energy efficiency technologies.

- Carry out a resource survey and assessment to determine the total renewable energy potential in the country as well as identify the local conditions and local priorities in various ecological zones.

- Establish a testing and standards laboratory for renewable energy technologies similar to that in South Africa.

- Take advantage of global partnerships, such as the Residential Energy Efficiency Project initiative of UK, to assist the country in a creative integration of renewable energy systems.

- Establish a renewable energy funding/financing agency such as India's Indian Renewable Energy Agency.

- Develop appropriate drivers for the implementation of energy efficiency policies.

- Clean energy facilities should be embraced in the different sectors of the Nigerian economy.

In the following, a partial list of potential clean energy opportunities in Nigeria is presented:

- More efficient passive and full usage of solar technologies in the residential, commercial, and industrial sectors.

- Biogas from wastes as a source of cooking fuel in homes.

- Use of energy-efficient lighting.

- Implementation of renewable biomass as a fuel in highly efficient cook stoves.
- Efficient production of charcoal as a fuel in homes and small and medium enterprises.

- Use of biofuels in efficient cooking stoves and lamps in homes.

- Energy-efficient lighting.

- Use of compressed natural gas (CNG) as a transport fuel.

- Use of biofuels as a transport fuel.

- Introduction of a bus rapid transit system to other cities and expansion of the Lagos system.

- Shift from high carbon intensive fuels to natural gas for energy generation in industries.

- Development of a CNG infrastructure to distribute natural gas to industries located at sites remote from the existing pipelines.

- Implementation of combined heat and power (CHP) facilities in industries.

- Implementation of energy efficiency improvements in manufacturing industries.

- Implementation of CHP facilities in commercial facilities.

- Use of solar and wind energy for irrigation water pumping and farm electricity supply.

- Utilization of agricultural residues for electricity generation.

- Generation of biogas from wastes produced by the livestock and animal husbandry.

In addition to these, the existing research and development centers and technology development institutions should be adequately strengthened to support the shift towards an increased use of renewable energy. Human resource development, critical knowledge, and knowhow transfer should be the focus for project development, project management, monitoring, and evaluation. The preparation of standards and codes of practices, maintenance manuals, life cycle costing, and cost-benefit analysis tools should be undertaken on urgent priority.

\section{Competing interests}

The author declares that there are no competing interests.

Received: 1 November 2011 Accepted: 10 July 2012

Published: 23 July 2012

\footnotetext{
References

1. Ramchandra P, Boucar D (2011) Green Energy and Technology. Springer London Dordrecht Heidelberg New York

2. Rai GD (2004) Non- Conventional Energy Sources. Khanna Publishers, Delhi

3. Nnaji C et al (2010) In: Nnaji CE, Uzoma CC (eds) CIA World Factbook., Nigeria, http://www.cia.gov/library/publications/the-world-factbook/geos/ni. html

4. Council for Renewable Energy, Nigeria (CREN) (2009) Nigeria Electricity Crunch. available at www.renewablenigeria.org

5. CBN (1985) Central Bank of Nigeria Annual Reports and Statement of Account

6. Department of Petroleum Resources (DPR) (2007) Nigeria, Nigeria, available at http://www.DPR.gov.ng
} 
7. Onyebuchi El (1989) Alternative energy strategies for the developing world's domestic use: A case study of Nigerian household's final use patterns and preferences. The Energy Journal 10(3):121-138

8. Chineke TC, Igwiro EC (2008) Urban and rural electrification: enhancing the energy sector in Nigeria using photovoltaic technology. African Journal Science and Tech 9(1):102-108

9. Energy Commission of Nigeria (ECN) (2005) Renewable Energy Master Plan

10. Adekoya LO, Adewale AA (1992) Wind energy potential of Nigeria. Renewable Energy 2(1):35-39

11. Fagbenle RO, Karayiannis TG (1994) On the wind energy resources of Nigeria. International Journal of Energy research 18(5):493-508

12. Ngala GM, Alkali B, Aji MA (2007) Viability of wind energy as a power generation source in Maiduguri, Borno state, Nigeria. Renewable energy 32 (13):2242-2246

13. Akinbami JFK (2001) Renewable Energy Resources and Technologies in Nigeria: Present Situation, Future Prospects and Policy Framework'. Mitigation and Adaptation Strategies for Global Change 6:155-181. Kluwer Academic Publishers, Netherlands

14. Akinbami JFK, llori MO, Oyebisi TO, Akinwumi IO, Adeoti O (2001) Biogas energy use in Nigeria: Current status, future prospects and policy implications. Renewable and Sustainable Energy Review 5:97-112

15. Sambo AS (2008) Matching Electricity Supply with Demand in Nigeria. International Association of Energy Economics 4:32-36

16. Ighodaro CAU (2010) Co-Integration And Causality Relationship Between Energy Consumption And Economic Growth: Further Empirical Evidence For Nigeria. Journal of Business Economics and Management 11(1):97-111

17. Okafor ECN, Joe-Uzuegbu CKA (2010) Challenges To Development Of Renewable Energy For Electric Power Sector In Nigeria. International Journal Of Academic Research 2(2):211-216

18. Energy Commission of Nigeria (ECN) (2007) Draft National Energy Masterplan

19. (August 2000) Report of the Inter-Ministerial Committee on Combating Deforestation and Desertification

20. Famuyide OO, Anamayi SE, Usman JM (2011) Energy Resources' Pricing Policy And Its Implications On Forestry And Environmental Policy Implementation In Nigeria. Continental J Sustainable Development $2: 1-7$

21. Sambo AS (2009) Strategic Developments in Renewable Energy in Nigeria. International Association of Energy Economics 4:15-19

22. Energy Commission of Nigeria (ECN) (2003) National Energy Policy. Federal Republic of Nigeria, Abuja

23. Abiodun R (2003) Fuel price Hike Spells Doom for Nigeria's Forest., , htt: www.islamonline.net/English/index.shtml

24. Williams CE (1998) 'Reaching the African Female Farmers with Innovative Extension Approaches: Success and Challenges for the Future'. Paper Presented To The International Workshop on Women Agricultural Intensification and Household Food Security At University of Cape Coast, Ghana, 25th-28th June

25. Karekezi R (1997) Renewable Energy Technologies in Africa, Zed Books Limited with African Energy Policy Research Network (AFREPREN) and Stockholm Environment Institute (SEI)

26. Central Bank of Nigeria (CBN) (2000) 'The changing structure of the Nigerian economy and implications for development'. Research Department, Central Bank of Nigeria; Realm Communications Ltd, Lagos, August

27. Famuyide OO, Adu AO, Ojo MO (2004) Socio-Economic Impacts of Deforestation in the Sudano- Sahelian Belt of Nigeria. Journal of Forestry Research and Management 1(1\&2):94-106

28. Fagbenle RO, Adenikinju A, Ibitoye Fl, Yusuf AO, Alayande O (2006) Draft Final Report on Nigeria's Electricity Sector Executive Report

29. PHCN (2008) Generation and Transmission Grid Operations. Annual Technical Report National Control Center (NCC), Osogbo

30. PHCN (2009) Generation and Transmission Grid Operations. National Control Center (NCC), Osogbo

31. Imo EE (2008) 'Challenges of Hydropower Development in Nigeria'. Hydrovision

32. CBN (Central Bank of Nigeria) (2007), Vol. 18th edn., December

33. Emeka EE (2010) 'Causality Analysis of Nigerian Electricity Consumption and Economic Growth'. Journal of Economics and Engineering 4:80-85, ISSN: 2078-0346
34. Odularu GO, Okonkwo C (2009) 'Does Energy Consumption Contribute To Economic Performance? Empirical Evidence From Nigeria', Journal of Economics and Business Vol. XII, No 2:43-47

35. CBN (2009) Central Bank of Nigeria Statistical Bulletin. CBN Press, Abuja

36. UNIDO (United Nations Industrial Development Organization) (2001) UNIDO (United Nations Industrial Development Organization). UNIDO (United Nations Industrial Development Organization), UNIDO (United Nations Industrial Development Organization)

37. Ajayi OO, Ajanaku KO (2007) Nigeria's Energy Challenge and Power Development: The Way Forward. Bulletin of Science Association of Nigeria 28:1-3

38. Iwayemi A (2008) Nigeria's Dual Energy Problems: Policy Issues and Challenges. International Association for Energy Economics., , pp 17-21, Fourth Quarters

39. Ibitoye F, Adenikinju A (2007) (2007) Future Demand for Electricity in Nigeria. Applied Energy 84:492-504

40. Adenikinju A (2005) ' Analysis of the cost of infrastructure failures in a developing economy the case of electricity sector in Nigeria'. African Economic Research Consortium AERC Research Paper 148, Nairobi, February 2005

41. Mitchel JW (1983) Energy engineering. John Wiley and Sons, New York

42. Adeyemo SB (2001) 'Energy potentials of organic wastes'. In: Proceedings of the first national conference., , pp 55-61, ISBN 978-35533-0-5

43. Sambo AS, Iloeje OCJ, Ojosu OJ, Olayande S, Yusuf AO (2006) Nigeria's Experience on the Application of IAEA $\square$ s Energy Models (MAED \& WASP) for National Energy Planning, Paper presented during the Training Meeting / Workshop on Exchange of Experience in Using IAEA's Energy Models and Assessment of Further Training Needs. held at the Korea Atomic Energy Research Institute, Daejon, Republic of Korea, pp 24-28, April

44. Energy Commission of Nigeria (ECN) (2006) National Energy Policy. Federal Republic of Nigeria, Abuja

45. Ohunakin OS (2010) Energy utilization and renewable energy sources in Nigeria. Journal of Engineering and Applied Sciences 5(2):171-7

46. Energy Commission of Nigeria (ECN) (2008) National Energy Policy. Federal Republic of Nigeria, Abuja

47. CBN (2006) Central Bank of Nigeria Statistical Bulletin. CBN Press, Abuja

48. National Bureau of Statistics (NBS) (2007) National Core Welfare Indicator Questionnaire (CWIQ) Survey. National Bureau of Statistics (NBS), Abuja, p 2, Summary Sheet

49. CBN (2005) Central Bank of Nigeria Statistical Bulletin. CBN Press, Abuja

50. Hui SCM (1997) From renewable energy to sustainability: the challenge for Honk Kong'. Hong Kong Institution of Engineers :351-358

51. Lior N (2008) Energy resources and use: The present situation and possible paths to the future. Energy 33:842-857

52. Haberl $H$ (2006) The global socioeconomic energetic metabolism as a sustainability problem. Energy 31:87-99

53. Rosen MA (2002) Energy efficiency and sustainable development. Int J Global Energy Issues 17:23-34

54. Ayres RU, Turton H, Casten T (2007) Energy efficiency, sustainability and economic growth. Energy 32:634-648

55. Rosen MA (2009) Energy Sustainability: A Pragmatic Approach and illustrations. Sustainability 1:55-80

56. Ashong SN (2001) Macroeconomic Framework for Poverty Reduction Within the Context of Debt Relief:The Case of Ghana. Paper Presented at WIDER Development Conference on Debt Relief Helsinki, Finland

57. Hammond GP (1998) Alternative energy strategies for the United Kingdom revisited; market competition and sustainability. Technological Forecasting and Social Change 59:131-151

58. Sims REH, Schock RN, Adegbululgbe A, Fenhann J, Konstantinaviciute I, Moomaw W, Uyigue E (2007) CREDC Conference on Promoting Renewable Energy and Energy Efficiency in Nigeria. held at University of Calabar Hotel and Conference Centre, $21^{\text {st }}$ November

59. Winkler H (ed) (2006) Energy policies for sustainable development in South Africa Options for the future. Energy Research Centre University of Cape Town, Private Bag Rondebosch 7701 South Africa, Website: www.erc.uct.ac.za

60. SECCP (2002) 'Getting to grips with sustainable energy'

61. Adeyemo SB, Odukwe AO (2008) 'Energy Conservation as a Viable Pathway towards Energy Stability. Journal of Engineering and Applied Sciences 3(3):233-238 
62. Habib MA, Said SAM, Igbal MO, El-Mahallawy FM, Mahdi EA (1999) Energy Conservation and Early Failure Prediction in Boilers and Industrial Furnaces Symposium on Management of Energy Consumption in Industry, Chamber of Commerce, Dammam, Kingdom of Saudi Arabia, October

63. Dubin FS, Long CG (1980) 'Energy conservation standards for Building design, construction and operation. McGraw- Hill Book Company

64. Etiosa U (ed) (2009) Energy Efficiency Survey in Nigeria: A Guide for Developing Policy and Legislation. International, Rivers, pp 1-37

65. Uyigue E (2007) 'Renewable energy and energy efficiency and sustainable development in Nigeria'. In: CREDC Conference on Promoting Renewable Energy and Energy Efficiency in Nigeria

66. Sarah La P (2002) 'Climate Change and Poverty'. A Publication of Tearfund

67. Winkler H, Van Es D (2007) Energy Efficiency and CDM in South Africa: Constraints and Opportunities. Journal of Energy in South Africa 18:29-37

68. Dayo FB (2008) Clean Energy Investment in Nigeria The domestic context. International Institute for Sustainable Development (IISD)

69. The United Nations (UN) (1993) Report on the National Fuel wood Substitution Programme. United Nations Publications, New York, Energy Statistics Yearbook

70. Martinot E, McDom O (2002) Promoting Energy Efficiency and Renewable Energy GEF Climate Change Projects and Impacts; Global Environmental Facility. Washington, DC

71. lyayi F (2004) 'An integrated approach to development in the Niger Delta'. A paper prepared for the Centre for Democracy and Development (CDD)

72. Awosika LF (1995) Impacts of global climate change and sea level rise on coastal resources and energy development in Nigeria. In: Umolu JC (ed) Global Climate Change:Impact on Energy Development. DAMTECH Nigeria Limited, Nigeria

doi:10.1186/2192-0567-2-15

Cite this article as: Oyedepo: Energy and sustainable development in Nigeria: the way forward. Energy, Sustainability and Society 2012 2:15.

\section{Submit your manuscript to a SpringerOpen ${ }^{\circ}$ journal and benefit from:}

- Convenient online submission

- Rigorous peer review

- Immediate publication on acceptance

- Open access: articles freely available online

- High visibility within the field

- Retaining the copyright to your article

Submit your next manuscript at $\gg$ springeropen.com 